\title{
TOXICITY OF CERTAIN COPPER FUNGICIDES AND OTHER PESTICIDES TO TERRESTRIAL SNAILS \\ El-Shahaat, M.S. ${ }^{1}$; Nagda A. Aly²; E. H. Eshra ${ }^{3}$; H. A. Mesbah ${ }^{2}$ and \\ Emtiaz I. Ghoneim ${ }^{3}$ \\ ${ }^{1}$ Central Agric. Pesticides Laboratory, Agric. Res. Center, Egypt. \\ ${ }^{2}$ Dept. of Plant Protection Fac. of Agric. (Saba Basha), Alex. Univ,Egypt \\ ${ }^{3}$ Plant Protection Res. Institute, Agric. Research Center, Egypt.
}

\begin{abstract}
Toxicity of certain copper fungicides to the small garden snail, Theba pisana was evaluated fed on sprayed cabbage leaves at the concentrations of $0.5 \%, 0.25 \%$ and $0.125 \%$. According to $L T_{50}$ values. The obtained $L T_{50}$ values were $4.67,5.18$ and 8.41 day, with copral; 5.62, 6.39. and 7.54 days for Kocide 2000. 5.47, 5.59 and 9.40 days for Galbin copper, respectively. Besides, molluscicidal efficacy of the copper fungicides, against the small garden snail, Theba pisana fed on sprayed lettuce leaves was carried out. The $\mathrm{LT}_{50}$ values expressed in were 2.67 for copper Acrobate (5\% Cu, as copper oxychloride), 3.50 for Kocide 2000 (5\% Cu, as copper hydroxide) and 2.17 for Galbine copper ( $5 \% \mathrm{Cu}$, as copper oxychloride + benalxyl).

On the other hand, the toxicity of poisoned baits against the brown garden snail, Eobonia vermiculata was assessed. Baits of methomyl ( $2 \%$ a.i.), cadusafos ( $2 \%$ a.i.), carbendazim ( $2 \%$ a.i.), Copral ( $5 \% \mathrm{Cu})$, Kocide 2000 (5\% Cu) and imidichlopride ( $2 \%$ a.i), gave $L T_{50}$ values of $1.54,6.19,7.00,4.39,4.94$ and 6.52 days, respectively.

Toxicity of poison baits to the white sand snail, Helicella vestalis was assessed by baits of Lannate (methomyl) 2\% a.i., Rugby (cadusafos) $2 \%$ a.i., Kocide 2000 Copper oxychloride $(2 \% \mathrm{Cu})$, kemazed (carbendazim)., $2 \%$ a.i, and Confidor (imidichlopride) $2 \%$ a.i. The obtained $\mathrm{LT}_{50}$ values were $3.40,6.48,10.62,6.10$ and 8.73 days, respectively.
\end{abstract}

\section{INTRODUCTION}

Land snails are considered as serious economic pests in the world due to its considerable damage of several types of plants. These attack leaves, flowers, roots, buds, and even the trunk of trees. In Egypt, the land snails are known as a dangerous pests to field crops, vegetables, orchards and ornamental plants especially in the northern coastal areas (El-Okda 1980, Ghamry et,al 1993, El-Deeb et,al 1996 and Eshra 2004). The present study is aimed to evaluate the toxicity of cooper fungicides; Copral $50 \%$, Galben copper 46\% WP, Acrobat copper 46\% WP, kocide $200053.8 \%$ DF (copper hydroxide), Kemazed 50\% WP (carbendazim), and copper sulfate against. Also certain insecticides; Lannet 90\% (methomyl), Rugpy 10\% G, (cadusafos), and Confidor 20\% SC (imidichlopride) were evaluated against Eobnia vermiculata, Helicella vestalis and Theba pisana land snails under laboratory conditions.

\section{MATERIALS AND METHODS}

\section{Snails}

The adults of the brown garden snail, Eobania vermiculata (Muller), the small sand snail, Helicella vestalis (Pfeifer) and the small garden snail, 


\section{El-Shahaat.M.S. et al.}

Theba pisana (Muller) were collected from Alexandria and El-Beheira Governorates and fully acclimatized to laboratory conditions prior to the testing and fed on lettuce leaves prior to the experiments.

\section{2. pesticides used}

\subsection{Funficides}

Copral 50\% WP; copper oxychloride

Galbin copper 46\% WP; benalaxyl (Methyl N-Phenyl acetyl-N-2,6 xylyl-DLalanninate) + copper oxychloride

Acrobat copper 46\% WP; dimethomorph ( E, Z) : 4-[3-4-chlorophenyl]-3-(3,4dimethoxy phenyl) acrylayl)] morphaline.

kocide (2000) 53.8\% DF ; Copper hydroxide $\left(\mathrm{Cu}(\mathrm{OH})_{2}\right)$

Kemazed 50\%WP: methylbenzimidazol-2-ylcarbamate

Copper sulfate $43 \%$ WP; $\left(\mathrm{CuSO}_{4} .5 \mathrm{H}_{2} \mathrm{O}\right)$

\section{2. insecticides}

Lannet 90\% SP:(Methomyl); S-methyl N-(methyl carbamoyloxy) thioacetimidate.

Rugpy10\% GR: (Cadusafos); S,S-di-Sec-Natyl-O-ethyl Phosphorodithioates.

Confidor: (Imidacoloporide); 1-(6-chloro-3- = pyridylmthyl)-N-nitromidazolidin2-ylideneamine.

\section{Poison bait preparation :}

The toxic baits were prepared using botanical bi-products and the above mentioned commercial formulations of the pesticides. The botanical substances were used as carriers and food attractants. The chosen substances were wheat bran (fine fraction) and fine fraction of sawdust in a mixture of $(1: 1 \mathrm{w} / \mathrm{w})$. The appropriate amount of each tested pesticide was well mixed with a mixture of acetone : ethanol : water $(3: 1: 0.5 \mathrm{v} / \mathrm{v})$ or water only with the copper fugicides, and mixed with wheat bran + sawdust mixture $1: 1(\mathrm{w} / \mathrm{w})$. The obtained baits were coloured using an aqueous solution of a blue paint substance $(0.5 \%)$ as colour attractant for gastropods. The prepared baits involved pesticides in their concentrations as follows: Kocide 2000 (5\% Cu as copper hydroxide), Acrobate/copper (5\% Cu as copper oxychloride), Copral (5\% Cu as copper oxychloride), Galben/copper (5\% Cu as copper oxychloride), Confidor ( $2 \%$ imidachlopride) and Rugby (2\% cadusafos). The methomyl bait ( $2 \%$ a.i) is used as a standard molluscicide.

\section{Laboratory molluscicidal activity of certain pesticides:}

The laboratory tests were carried out in sealed plastic vessels $(22 \mathrm{x}$ $15 \times 10 \mathrm{~cm}$ ) with three replicates, each contains 10 adults of the chosen snail species with similar shell size and replicated three times. Four tests were done. The $1^{\text {st }}$ one was carried out to evaluate the efficiency of some copper fungicides against Theba pisana snail according bioassay feeding technique therefore sprayed cabbage leaves have been offered as discs of approximately $5 \mathrm{~cm}$ diameter. The treatments were; Copral, Kocide 2000, and Galben/copper. Each fungicide was sprayed on leaves at three aqueous concentrations; $0.50,0.25$ and $0.125 \%$. The $2^{\text {nd }}$ test was carried out using the same technique with lettuce leaves which have been sprayed with Acrobate copper $(5 \% \mathrm{Cu})$, Kocide $2000(5 \% \mathrm{Cu})$ and Galben copper $(5 \% \mathrm{Cu})$ and offered to Theba pisana snail. The $3^{\text {rd }}$ test was excuted with Eobania 
vermiculata snail which exposed to baits of cadusafos ( $2 \%$ a.i), carbendazim $(2 \%$ a.i), Copper oxychloride $(5 \% \mathrm{Cu})$, copper hydroxide $(5 \% \mathrm{Cu})$, imidachlopride ( $2 \%$ a.i) and methomyl ( $2 \%$ a.i). The $4^{\text {th }}$ test was executed out with Helicella vestalis snail using $2 \%$ poison baits of methomyl, cadusafos, copper hydroxide, imidachlopride and carbendazim pesticides.

Moreover, in the all prementioned tests, the killed snail individuals were removed daily and the accumulative mortality effects were recorded up to 6 or 7 days post treatment. The mortality percentages were corrected using Abbott's formula (1925) and then exposed to the angular transformation. The lethal time (LT50) for $50 \%$ mortality was estimated.

\section{RESULTS AND DISCUSSIONS}

\section{Bioassay of the tested fungicides against certain land snails:}

The efficiency of certain copper fungicides against the small garden snail, Theba pisana (Muller) was evaluated by feeding the snails on sprayed cabbage leaves under laboratory conditions. Results shown in Table (1) indicated that the calculated mortality values (\%) as a cumulative effect up to 6 days of treatment, were gradually increased with time.

Table (1): Toxicity of certain copper fungicides against the small garden snail, Theba pisana (Muller) fed on sprayed cabbage leaves.

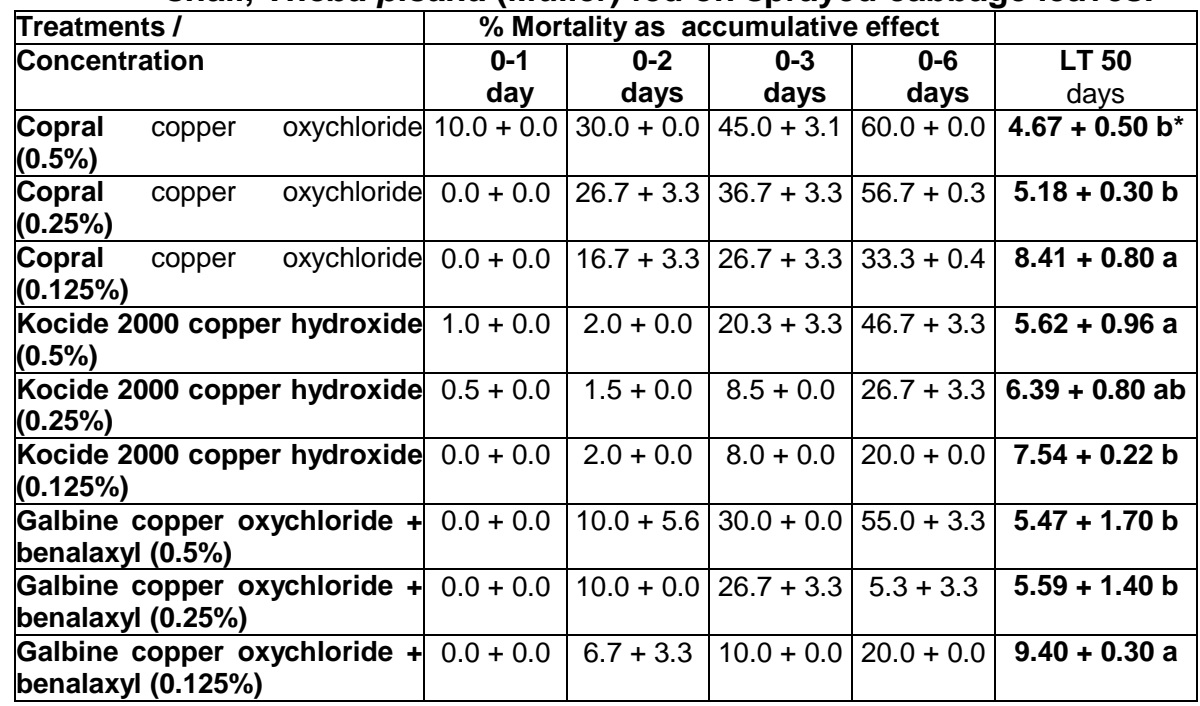

*: Values with some letters are not statistically different.

The deduced mortality values were $60.0,56.7$ and $33.3 \%$ after 6 days after snails fed on the treated leaves with copper oxychloride fungicide at the concentrations of $0.5 \%, 0.25 \%$ and $0.125 \%$, respectively. The corresponding $\mathrm{LT}_{50}$ values were $4.67,5.18$ and 8.41 respectively. Mean while $\%$ mortality values for copper hydroxide amounted 46.7, 26.7 and 20.0, respectively. These values were corresponded to $\mathrm{LT}_{50}$ values of $5.62,6.39$ 


\section{El-Shahaat.M.S. et al.}

and 7.54 days at its tested concentrations of $0.5 \%, 0.25 \%$ and $0.125 \%$, respectively. The same concentrations of Galbine copper fungicide $(0.5,0.25$ and $0.125 \%$ ) gave \% mortality values of $55.0,53.2$ and 20.0 corresponding with the calculated $L T_{50}$ values of $5.47 \%, 5.59$ and 9.40 , respectively.

Molluscicidal effect of the tested copper fungicides against the small garden snail, Theba pisana on laboratory treated lettuce leaves is shown in Table (2). The \% mortality as accumulative effect indicated that the fungicides could be descendingly arranged as follows: Kocide (2000) or/and Galbine copper $(5 \% \mathrm{Cu})(100.0 \%$ mortality) > Copper acrobate, $(84.3 \%)$. According to the substracted $\mathrm{LT}_{50}$ values, it is clear that Galbine copper fungicide had the highest effect to kill $50 \%$ of the treated snails.

These results exhibit that the Copper fungicides may be useful as molluscicides through spraying application on vegetable plants at the concentration rate of $0.5 \%$. Herein, these tested inorganic compounds appeared to be effective as molluscicides. The efficiency of inorganic copper salts are in agreement with those obtained by many investigators (Lang and Mocleods, 1941; Glendonning, 1952; Winkler and Chi, 1964; Barry, 1969; Van Dinther, 1973 and Shoeb, 1975) and El-Shahaat et al. (under publication). El-Wakil and Mesbah (1995) evaluated the low concentrations of Copper sulfate solutions; $(0.25,0.5,1.0$ and $1.5 \mathrm{~g} / \mathrm{L}$ water on the infestation rate with Theba pisana (Muller) snails for Vicia faba L., in the field. During the first 45 days of the experiment, the plants were sprayed after germination every 15 days for three times with each tested concentration. The occurred number of Theba pisana snails on the treated plants were monthly counted along five months from January to May.

Table (2): Molluscicidal efficacy of certain copper fungicides against the small garden snail, Theba pisana (Muller) fed on treated lettuce leaves.

\begin{tabular}{|l|r|r|r|r|c|}
\hline Fungicides & \multicolumn{3}{|c|}{$\%$ Mortality as a accumulative effect } & \\
\hline & $\mathbf{0 - 1 d a y}$ & $\mathbf{0 - 2 d a y s}$ & $\mathbf{0 - 3 d a y s}$ & $\mathbf{0 - 5 d a y s}$ & LT 50(Days) \\
\hline $\begin{array}{l}\text { Acrobate copper; 5\% Cu (as } \\
\text { copper oxychloride) }\end{array}$ & $25.0+0.0$ & $50.0+0.0$ & $65.3+2.9$ & $84.3+3.0$ & $\mathbf{2 . 6 7} \mathbf{~ b}$ \\
\hline $\begin{array}{l}\text { Kocide; 2000 5\% Cu (as } \\
\text { copper oxychloride) }\end{array}$ & $66.7+4.4$ & $46.0+2.9$ & $96.3+0.7$ & $100.0+0.0$ & $\mathbf{3 . 5 0} \mathbf{~ a}$ \\
\hline $\begin{array}{l}\text { Galben copper; 5\% Cu (as } \\
\text { copper oxychloride) }\end{array}$ & $36.0+2.1$ & $45.0+5.8$ & $70.7+5.8$ & $100.0+0.0$ & $\mathbf{2 . 1 7} \mathbf{~}$ \\
\hline
\end{tabular}

* : Values having the same letters are not statistically different.

It was also obtained that a significant decrease in the numbers of snails among different treatments was achieved. The concentrations of 1.0 and $1.5 \mathrm{~g} / \mathrm{L}$ exhibited the highest effects in decreasing the percentage number of snails at the end of the experiment $(96.56 \%)$. The concentration of $1.5 \mathrm{~g} / \mathrm{L}$ copper sulfate solution gave the highest productivity of plants and decrease in the number of occurring snails. The toxicity and efficacy of copper fungicides may be attributed to the explaination reported by Schiide et al. (2003) who concluded that the foots of the terrestrial gastropods are the sites of copper uptake. The foot is an important penetration routs for highly soluble copper salt, which can be expected to cause some internal damage 
and irritant effects. These illustrations are paralleled with that previously reported by Ryder and Boweron (1977). Also, the irrilation effect of copper salts can cause significant dehydrogenation of snails and slugs.

Results in Table (3) indicate the toxicity of prepared poison baits of certain tested pesticides against the white sand snail, Helicella vestalis. The a accumulative \% mortality values amounted to $100.0,35.0,21.3,42.3$ and 15.3 up to 6 days of feeding on the prepared baits of methomyl (Lannate), Cadusafos (Rugby), Carbendazim (Kemazed), Kocide 2000 and Imidachlopride (Confider), respectively. These results corresponded to the $\mathrm{LT}_{50}$ values of $3.40,6.48,10.62,6.10$, and 8.73 days, respectively.

Table (3): Toxicity of tested poison baits to the White Sand snail, Helicella vestalis (Preifer).

\begin{tabular}{|c|c|c|c|c|c|c|c|}
\hline \multirow[t]{2}{*}{ Baits } & \multicolumn{6}{|c|}{$\begin{array}{l}\text { accumulative corrected mortality } \% \\
\text { at indicated days }+\mathrm{SD}^{\star}\end{array}$} & \multirow[t]{2}{*}{$\begin{array}{l}\text { LT } 50 \\
\text { (Days) }\end{array}$} \\
\hline & $\begin{array}{l}0-1 \\
\text { day }\end{array}$ & $\begin{array}{c}0-2 \\
\text { days }\end{array}$ & $\begin{array}{c}0-3 \\
\text { days }\end{array}$ & $\begin{array}{c}0-4 \\
\text { days }\end{array}$ & $\begin{array}{c}0-5 \\
\text { days }\end{array}$ & $\begin{array}{l}0-6 \\
\text { days }\end{array}$ & \\
\hline $\begin{array}{l}\text { Methomyl } \\
(2 \% \text { a.i })\end{array}$ & $14.6+1.1$ & $36.7+1.2$ & $56.6+1.1$ & $70.3+1.7$ & $90.0+1.0$ & $100.0+0.0$ & $3.40 \mathrm{~d}$ \\
\hline $\begin{array}{l}\text { Cadusafos } \\
(2 \% \text { a.i })\end{array}$ & $2.0+1.2$ & $4.7+2.7$ & $16.7+1.7$ & $23.3+1.0$ & $28.7+2.1$ & $35.0+3.1$ & $6.48 \mathrm{c}$ \\
\hline $\begin{array}{l}\text { Carbendazim } \\
(2 \% \text { a.i) }\end{array}$ & 0.0 & $10.0+1.5$ & $12.3+2.0$ & $14.7+3.5$ & $17.3+1.2$ & $21.3+0.7$ & $10.62 \mathrm{a}$ \\
\hline $\begin{array}{l}\text { Kocide } 2000 \\
(2 \% \text { Cu })\end{array}$ & $1.7+2.5$ & $5.0+1.4$ & $12.3+2.6$ & $24.3+1.1$ & $30.0+2.0$ & $42.3+2.7$ & $6.10 \mathrm{c}$ \\
\hline $\begin{array}{l}\text { Imidachlopride } \\
(2 \% \text { a.i })\end{array}$ & 0.0 & 0.0 & $3.7+1.0$ & $6.7+0.7$ & $8.3+1.0$ & $15.3+0.9$ & $8.73 \mathrm{~b}$ \\
\hline
\end{tabular}

* : Each value is an average of 5 replicates (10 snail each) + standard deviation and the values with the same letters are not significantly different.

From the obtained results it could be noticed that the highest toxicity effect was recorded with for methomyl bait ( $2 \%$ a.i.); followed by the fungicide Kocide 2000 bait $(2 \% \mathrm{Cu})$; while the remaining pesticides gave less efficacy.

In addition, the results illustrated in Table 4 elucidate the toxicity of the poison baits of six tested pesticides to the brown garden snail, Eobania vermiculata.

Table (4): Toxicity of poison baits to the brown garden snail, Eobania vermiculata (Muller).

\begin{tabular}{|c|c|c|c|c|c|}
\hline \multirow{3}{*}{ Baits } & \multicolumn{4}{|c|}{ accumulative corrected mortality $\%$ + SD* } & \multirow{3}{*}{ LT $50^{* \star \star}$} \\
\hline & \multicolumn{4}{|c|}{ Days of assay } & \\
\hline & $\begin{array}{l}0-1 \\
\text { day }\end{array}$ & $\begin{array}{c}0-2 \\
\text { days }\end{array}$ & $\begin{array}{c}0-5 \\
\text { days }\end{array}$ & $\begin{array}{c}0-7 \\
\text { days }\end{array}$ & \\
\hline Methomyl bait $\left(2 \%\right.$ a.i) ${ }^{\star \star}$ & $33.1+1.7$ & $76.7+1.67$ & $91.6+2.2$ & $100.0+0.0$ & $1.54 \mathrm{~d}$ \\
\hline Cadusafos (2\% a.i) & $10.0+1.2$ & $25.0+2.90$ & $40.0+2.9$ & $55.0+1.7$ & $6.19 \mathrm{~b}$ \\
\hline Carbendazim (2\% a.i) & $0.0+0.0$ & $2.0+1.00$ & $23.0+2.4$ & $61.3+2.4$ & $>7.00 \mathrm{a}$ \\
\hline Copral $(5 \% \mathrm{Cu})$ & $20.0+2.9$ & $53.3+6.70$ & $63.3+1.7$ & $80.0+0.0$ & $4.39 \mathrm{c}$ \\
\hline Kocide 2000 (5\% Cu) & $10.0+1.2$ & $33.3+3.30$ & $53.3+3.3$ & $83.3+4.4$ & $4.94 \mathrm{c}$ \\
\hline Imidachlopride (2\%) & $5.3+0.9$ & $7.0+1.20$ & $25.0+5.0$ & $64.3+2.3$ & $6.52 \mathrm{~b}$ \\
\hline
\end{tabular}

* : Each value is an average of 3 replicates (10 snail each) + standard deviation.

** : This baits is taken as a standard treatment.

$\star \star \star$ : Lethal time (day) for $50 \%$ killing. 


\section{El-Shahaat.M.S. et al.}

The highest a accumulative mortality (\%) is recorded to methomyl (100.0\%) followed by Kocide 2000 (83.3\%) and Copral (80.0\%). The remainders gave lower values which are ranged between 55.0 and 64.3 indicating that Cadusafos had the lowest effect $(55.0 \%)$ after 7 days of exposure. The $L_{50}$ values confirmed that methomyl was the highest efficient treatments (1.54 days) followed by Copral (4.39 days) then Kocide (4.94 days).

From the above mentioned results it could be revealed that the applications of inorganic copper compounds either by foliar sprays or by involving then in poisonous baits were effective against the tested land snails.

\section{REFERENCES}

Abbott, W.S. (1925). A method of computing the effectiveness of an insecticide. J. Econ. Entomol., 18: 265-267.

Barry, B.D. (1969). Evaluation of chemicals for control of Slugs on field Corn in Ohio. J. Econ. Entomol., 62: 1277-1279.

El-Deeb, H.I. E.M. Ghamry. N. El-Hwashy and N. Essa (1996). Relative abundance of some and snails in certain Governorates of Egypt. J. Agric. Sci., Mansoura Univ., 21: 2977-2983.

El-Shahaat, M.S.; E.H. Eshra and Y. Abo Bakr (2009). Evaluation of urea fertilizer in comparison to conventional pesticides against terrestrial snails in fruit orchards. J. pest cont. \& Environ. Sci. In press.

El-Wakil, H.B. and H.A. Mesbah (1995). Effect of spraying copper snifate solution on the terrestrial snail Theba pisana (Mull.) and the productivity of Vicia faba (L). Com. in Sci. and Dev. Res., 786 (52): 981-88).

Eshra, H.E. (2004). Studies on terrestrial mollusca at some Governorates of West Delta with special reference to its integrated management. Ph. D. Thesis, Fac. Agric., Al-Azhar Univ., Egypt.

Ghamry, E.M.; H.I. El-Deeb and Y.A. Kokab (1993 ). Ecological and morphological studies on certain land snails at Sharkia Governorate, Egypt ., J. Appl. Sci., 8: 213-225.

Glendenning, R. (1952). Slug control in Canada. Proc. Publ. Series, No., 85, 1-5 Entom. Sci. Serv. Dep., Agric. Canada.

Lange, W.H.Jr. and G.F. Macleod (1941). Metaldehyde and calcium arsenate in slug and snail baits. J. Econ. Entomol., 34: 321-322.

Ryder, T.A. and I.D. Bowerorn (1977). The slug food as a site of uptake of copper molluscicide. J. Invert. Pathol., 30: 381-386.

Schiide, I.; G. Port. and J. Bennison (2003). Barriers, repellents and antifeedants for slug and snail control. Crop Prot., 22: 1033-1038.

Shoeb, H.A. (1975). The chemistry of molluscicides. Egypt. J. Bull., 2: 151175.

Van Dinther, J. (1973). Molluscs in agriculture and their control. Meded. Lab. Entom. Wageningen, 232, 281-286, World Crops 11/12.;

Winkler, L.R. and L.W. Chi (1964). Defensive mechanisms of the schistosome snail host oncomr lania formosana against copper sulfate in adult and egg stages. Amer. J. Trop. Med. Hyg., 13: 897-907. 
سمية بعض مبيدات الفطريات النحاسية والمبيدات الأخرى ضد القواقع الأرضية ، القدية

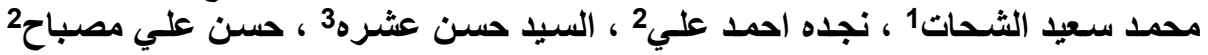
وامتياز إبراهيم غنيم3 الفيدات

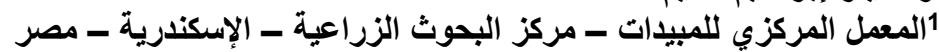

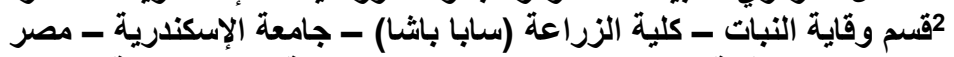

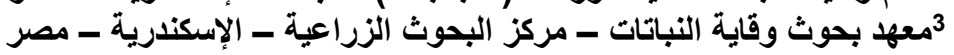

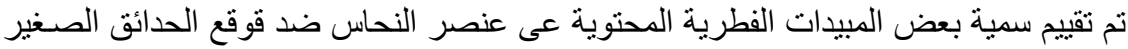

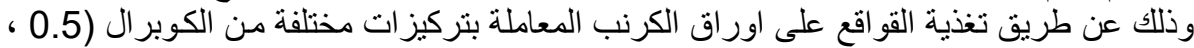

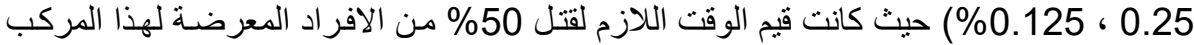

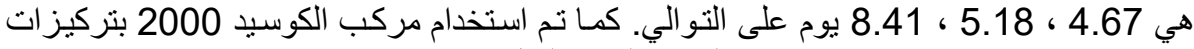

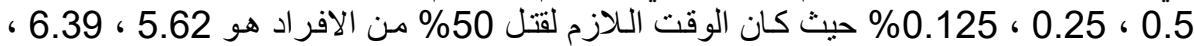

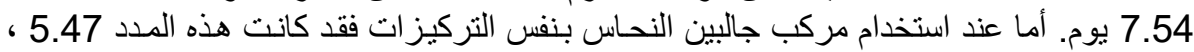

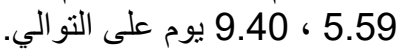

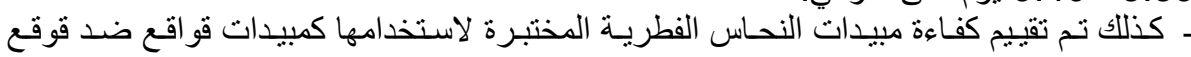

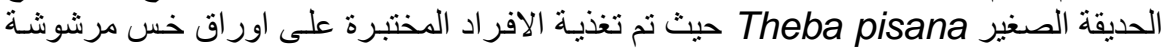

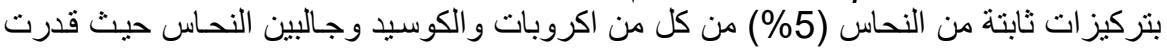

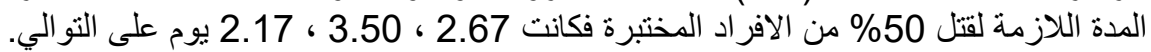
- بالاضافة الى تقييم سمية بعض الطعوم على قوقع الرمل الابيض

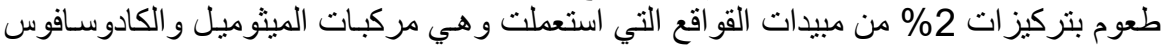

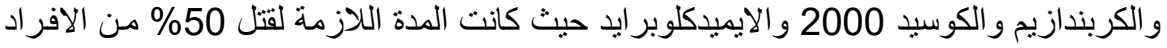

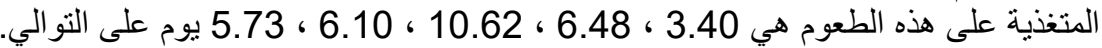

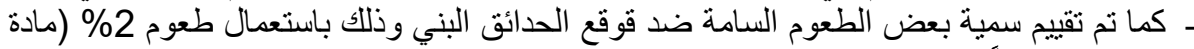

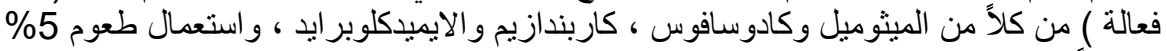

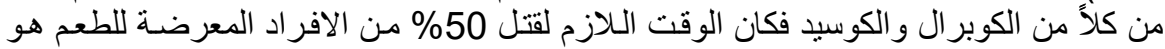
1.54 ، 6.19 ، 7.00 ، 7.00 ، 4.39 و 6.52 يوم على التوالي. 